\title{
Bildung, the Bologna Process and Kierkegaard's Concept of Subjective Thinking
}

\author{
Solveig M. Reindal
}

Published online: 25 December 2012

(C) The Author(s) 2012. This article is published with open access at Springerlink.com

\begin{abstract}
The Bologna Framework for higher education has agreed on three "cycle descriptors"-knowledge, skill and general competence-which are to constitute the learning outcomes and credit ranges for the three cycles of higher education: The Bachelor, the Master and the $\mathrm{PhD}$. In connection with the implementations of the national qualification framework these descriptors initiated a new debate on the possibility of Bildung within higher education in Norway. Pursuing this question of whether the triad knowledge, skill and general competences makes possible or prevents Bildung within higher education I argue that regardless of how one conceptualizes Bildung, one must say something about the kind of thinking that initiates a process transforming knowledge to become internalised so as to influence one's choices and actions. A vital aim for the initiative of the Bologna process as envisioned in the Bologna Declaration 1999 was to develop a "Europe of Knowledge". Underpinning this and other educational documents it appears that lack of knowledge is seen as an important explanation to todays many challenges. A confidence in knowledge per se as having a transformative power in itself seems to be a belief supporting the knowledge policy that dominates official documents. Following Kierkegaard and his critique of becoming objective as nurturing disinterestedness, I am critical to an understanding of knowledge as transformative in itself if knowledge primarily is understood as objective knowledge. In this paper I argue that in order to take responsibility for the knowledge one holds, a thinking which Kierkegaard calls subjective is an important contribution to one kind of thinking involved if knowledge shall initiate a transformation of one's life and thus foster responsibility.
\end{abstract}

Keywords Kierkegaard $\cdot$ Subjective thinking $\cdot$ Bologna process $\cdot$ Bildung $\cdot$ Higher education

\section{Introduction}

Let the scientific researcher labor with restless zeal, let him even shorten his life in the enthusiastic service of science and scholarship; let the speculative thinker spare

S. M. Reindal ( $\bowtie)$

NLA University College, P.O. Box 74 Sandviken, 5812 Bergen, Norway

e-mail: SolveigM.Reindal@NLA.no 
neither time nor effort-they are nevertheless not infinitely, personally, impassionedly interested. On the contrary, they do not want to be. Their observations will be objective, disinterested. With regard to the subject's relation to known truth, it is assumed that if only the objective truth has been obtained, appropriation is an easy matter; it is automatically included as part of the bargain, and am Ende [in the end] the individual is a matter of indifference. Precisely this is the basis of the scholar's elevated calm and the parroter's comical thoughtlessness. (Kierkegaard 1992, p. 22)

The Bologna Process has initiated a major change in higher education, in part because it seeks standardization through harmonising the higher educational systems of Europe (Fejes 2008a, b). Along with this standardization, the importance of education as the basis for sustained economic growth is emphasized (Bologna Declaration 1999; OECD 2001). A vital aim of education is to contribute to the development of a "Europe of Knowledge" as anticipated in the Bologna Declaration: "A Europe of Knowledge is now widely recognized as an irreplaceable factor for social and human growth" (ibid., p. 1). This logic of economic progress and a knowledge economy has also contributed to a "customerization" of teaching and learning (Love 2008) and to an understanding of knowledge as a commodity that should serve the best interests of a community (Barnett 1994).

The European Higher Education Area (EHEA), as envisaged in the Bologna Declaration, was launched in 2010 (Budapest-Vienna Declaration 2010). An important step in launching the EHEA was to establish a common European framework for qualifications that emphasizes learning outcomes as a common methodology for national frameworks.

To implement national qualifications frameworks with an understanding of and according to the same interpretation of the overarching European framework, a common methodology based on learning outcomes (i.e., knowledge, skills and competencies descriptors), as well as a common approach to their self-certification is required. (Bologna Follow-up Group 2009, p. 17)

With knowledge understood as learning outcomes, higher education becomes a "business" of knowledge production (Love 2008). To treat knowledge, skills and competencies as a qualifying framework is not new within the supra-national organizations in Europe. In the OECD report The Well-Being of the Nations (2001), human capital is defined as "The knowledge, skill, competencies and attributes embodied in individuals that facilitate the creation of personal, social and economic well-being" (ibid., p. 18). Whether knowledge, skills and general competences are used as descriptions in defining "human capital" or "learning outcomes", it is also these "descriptors", which, after the Bologna Process, lay the foundation for reflections on what an educated person is, on aims, and on conceptualizations of Bildung within higher education.

In this paper I will investigate ways of knowing or the kinds of knowledge that are emphasized in official documents in Norway. My line of argument concerning the concepts of knowledge in these official documents is this: If the documents primarily emphasize knowledge as being a matter of learning a specific content in order to trade it off in society as a solution to various social, political and global challenges, then knowledge is viewed as having a transformative power in itself. Following Kierkegaard, who, as the above quote indicates, sees this as problematic, I am critical to the belief that knowledge in itself has transformative power without a process of appropriation. Knowledge must somehow become a part of the bearer, internalized in such a way that it makes a difference in the person's own life. This active process brings about what Kierkegaard calls subjective knowledge (Piety 2010). I argue that underneath any conceptualizations of Bildung, there 
must be a process that initiates knowledge and allows it to become internalized and part of one's life. It is in relation to this endeavour that I turn to Kierkegaard's concept of subjective thinking.

The paper is structured in three parts. Part one concerns the discussion about Bildung from a sensible choice in contemporary debates on the Bologna Process in Norway and situates this discussion in relation to Kierkegaard's thinking. Part two investigates shifting concepts of knowledge in official Norwegian documents and raises the question of whether these concepts can underpin an ethical endeavour. Part three investigates Kierkegaard's concept of subjective thinking and discusses how it might contribute to the process of becoming responsible for the knowledge one holds.

\section{Bildung in Higher Education and the Relevance of Kierkegaard's Concept of Subjective Thinking}

In Norway the announced implementation of the national qualification framework (NQF) in 2012 initiated a renewed debate on Bildung within higher education. Dannelsesutvalget ${ }^{1}$ (Bostad et al. 2009) - a national independent committee in Norway,_-gave itself the task of reflecting on how Bildung could be attended to in light of the announced implementation of the NQF. With the concept of Bildung used in the Report on Yale College Education (2003), which emphasizes the liberal arts tradition as its starting point, the committee claimed there was no contradiction between the Bologna Process, with its basis on knowledge, skill and general competence, and what the committee suggests: "We in the committee collectively confirm that there are no discrepancies between what we suggest and what the Bologna Process stipulates" (Bostad et al. 2009, p. 47). Further it sees its role as being "to take the initiative to discuss the content of higher education" (ibid., p. 3). The committee recommends that the virtues embedded in the liberal arts tradition, as defined by the Yale report, should be kept closely linked with the criteria (descriptors) for educational qualification and the aims for higher education which the Bologna Process has developed (ibid., p. 47). In conclusion, the committee holds that its contribution is to argue for a liberal arts tradition—a general education—emphasizing character building: "We are not used to engaging in personal character-building at Norwegian universities. But perhaps we have something to learn from the USA just here" (ibid., p. 48). Hence the Dannelsesutvalg is not critical to the qualification framework per se as it sees the main challenge to be the question on content within higher education in relation to whether higher education initiates Bildung.

Dannelsesutvalget's recommendation to understand Bildung as a form of cultivation in the liberal arts tradition has triggered renewed public and scholarly debate on the concept in Norway. One major contribution to this debate comes from a wide range of politicians and scholars in different fields (cf. Hagtvet and Ognjenovic 2011). A second committee is now continuing the discussion on Bildung within higher education. Following Dannelsesutvalget's lead, the Norwegian Association of Higher Education Institutions (UHR) has set up a committee whose task has been to report on good examples of how Bildung could be initiated within the organization's institutions (UHR 2011). In the same manner as

\footnotetext{
${ }^{1}$ Dannelsesutvalget (committee on Bildung) (Bostad et al. 2009) is now referred to as Dannelsesutvalget I since the work is continued by Dannelsesutvalget II. However, as the Dannelsesutvalget II has not delivered its final report, I will refer to Bostad et al. (2009) as Dannelsesutvalget.
} 
Dannelsesutvalget, the UHR committee has used the concept of Bildung developed in the Yale report as its starting point (Bostad et al. 2009, p. 9; UHR 2011, p. 13).

The Yale report highlights various virtues as normative-for instance, critical deliberation, curiosity, autonomy, involvement, collaboration and participation for the greater good. Thus the Yale report highlights the liberal arts tradition as a foundation for developing skills that can be brought to bear in whatever line of work a student eventually chooses.

Simultaneously as it points out the importance of liberal arts as a spur within higher education, the UHR committee also criticizes the Dannelsesutvalg. According to the UHR committee, the understanding of Bildung in Dannelsesutvalget's report is too philosophical: "While Dannelsesutvalget limits the concept of Bildung to the philosophical variety, the committee believes it is important to stress that Bildung occurs in all the disciplines, also in the technical and natural sciences" (UHR 2011, p. 10). Arguing thus for the need to broaden the platform for Bildung, the UHR committee divides the concept into seven categories: general, cultural, academic, professional, ethical, democratic and digital, emphasising the main task for universities and university colleges to be academic Bildung. This "is not understood primarily as the gaining of knowledge, but as the ability to be critical and to develop knowledge, viewing it in perspective and evaluating the quality of the elements of knowledge" (ibid., p. 7). Bildung, the UHR committee opines, cannot be attended to just by putting it on the agenda as part of a liberal arts curriculum. The scope of Bildung, the UHR asserts, is wider; "it is internalized knowledge and competence-that which is not inscribed in the curriculum" (ibid., p. 9). The matter of education-initiating Bildung, the UHR committee says, is especially relevant to the descriptions of learning outcomes in the NQF. This concerns general ethical competencies related to the development, presentation and stewardship of knowledge. Several of these concerns are attended to through the principle of research-based teaching, as described in Norway's 2005 Act of Universities and University Colleges. In sum, the UHR committee holds that "general competence" is the main concept in the triad because it attends to valuable aspects typical for Bildung as conceived in the Yale report.

However, the UHR committee is skeptical to the belief proposed by the Dannelsesutvalg, that it is possible to build character by merely changing the content of the curriculum in the direction of a liberal arts tradition. They argue that Bildung must not be isolated to specific courses since Bildung is interdisciplinary and multidisciplinary and must be problematized and concretized within the various disciplines and contexts:

The question is to what extent one can expect knowledge about Bildung to result in Bildung. Ethical Bildung is recognized through how it builds personal character and identity. Can the student increase his or her ability for ethical reflection by studying ethical theory, or improve in scientific reflection by studying the philosophy of science?

The UHR committee holds that it is not possible to add Bildung to the curriculum, as if it were a prescribed bit of knowledge or a learning goal. This argument we base on what has already been said, about Bildung as internalized knowledge and competence- "what we are left with after we have forgotten what we have learned". (UHR 2011, pp. 33-34, my translation)

The UHR committee does not, however, answer the question it poses, namely, to what degree can one expect that knowledge about Bildung results in Bildung? As I see it, this is the most fundamental question that needs to be asked in relation to Bildung and which 
neither the Dannelsesutvalg nor the UHR committee sufficiently problematize. If knowledge about something does not necessarily make a difference in a person's life it is important to ask: What kind of knowledge will make a difference and influence one's life as an existing being? Regarding this question it seems that it is important to pose the question of what kind of knowledge underpins the language of "knowledge" in official documents as the view of knowledge also influence the preconditions for Bildung.

The discussion on Bildung in Norway parallels a broader Nordic and international debate (cf. Biesta 2006; Horlacher 2004; Lieberkind and Bergstedt 2005; Løvlie et al. 2003; Masschelein and Ricken 2003; Rise 2010; Schneider 2012; Sünker 2006; Thompson 2005; Wahlström 2010). The investigations on Bildung in the research literature analyse the concept according to Løvlie and Standish (2003) in relation to three axes: cultivation and nature, private and public, and self-education and the cultivation of society. According to Masschelein and Ricken (2003), there are two main traditions: one tradition sees Bildung as a sort of canon indicating the cultural content of education; the other tradition emphasizes a specific kind of self-experience and self-development summarized in the phrase Sich-Bilden or "self-education". But the reason why Bildung has become the keyterm of the educational sciences is, according to Masschelein and Ricken, the fact that "Bildung is also used more and more to refer to a formal competency of acquiring currently required knowledge" (ibid., p. 141).

In the following, I will not elaborate on different conceptions of Bildung, but let Løvlie and Standish's normative definition form the basis for my own reflection, as their view of Bildung opens up for the dimension of viewing Bildung first and foremost as a question of being responsible in relation to oneself as a human being. In their analysis of the different contributions, Løvlie and Standish summarize Bildung in terms of the educated person:

The essays in this collection serve [...] to counteract the totalising and therefore oneeyed view of Bildung. All the contributors have used the term Bildung as a critical concept that has enabled them to ask critical questions of their own times [...] Instead of imposing formal notions of the educated person on the reader, they have summoned him or her to take responsibility for the humanity in his or her own person-and to take part in the ongoing conversation of mankind. The educated person, then, is the individual who strives towards being a competent contributor to that conversation. (Løvlie and Standish 2003, p. 23)

In their opinion, Bildung as a critical concept means to take responsibility for the humanity in one's own person and to contribute to the on-going conversation between educated persons. The crux here, in my view, is to take responsibility for the humanity in oneself, and I purposefully emphasize the word "responsibility". If we are to take responsibility for our humanness, we must be able to recognize a kind of thinking that will lead us to take responsibility entering the realm of the ethical.

Although we may disagree on what humanity is, we seem to react intuitively negative to certain acts and we label them inhuman. In this paper I put the term "humanity", as presented in the normative definition above, in brackets. I instead emphasize the term responsibility in the normative definition and concentrate on the kind of thinking needed for developing responsible humanity. This emphasis is grounded in my argument that in different conceptualizations of Bildung, there is the presupposition that one should be able to take responsibility for what one knows and act accordingly.

It is in relation to this active aspect - taking responsibility - that Kierkegaard's concept of subjective thinking is important. Kierkegaard distinguishes between the subjective and objective thinker in relation to ethical-religious issues and especially the questions 
concerning Christianity (Philosophical Fragments and The Concluding Unscientific Postscript). Kierkegaard's pseudonym Johannes Climacus, the author of Philosophical Fragments and Concluding Unscientific Postscript, is the scrutinizing epistemologist in these works investigating different ways of knowing. Kierkegaard uses this pseudonym when elaborating the distinction between objective and subjective thinking and ways of knowing. However, in the following I will refer to Kierkegaard, partly because the views historically associated with him mostly come from these two works (Evans 2006).

If knowledge, skill and general competence shall enable "education-initiating Bildung", these concepts must ensure the possibility of transforming the student subjectively and not simply provide objective knowledge for performing tasks valuable to a given society. We know intuitively that to be educated is more than just to have some kind of objective knowledge learned during formal education, some content in the mind that can be put to use in different situations. Being educated means taking the responsibility to develop one's own humanity as a unique individual. The problem of having an education, but one of serving an inhuman system, is powerfully expressed by a school principal who survived World War II:

Dear Teacher:

I am a survivor of a concentration camp. My eyes saw what no man should witness:

Gas chambers built by learned engineers.

Children poisoned by educated physicians.

Infants killed by trained nurses.

Women and babies shot and burned by high school and college graduates.

So, I am suspicious of education.

My request is: Help your students become human. Your efforts must never produce learned monsters, skilled psychopaths, educated Eichmann's.

Reading, writing and arithmetic are important only if they serve to make our children more humane. (Strom and Parsons 1994, pp. 519-520)

The principal calls for educated people who act responsibly in relation to their own knowledge and in such a way that they will not be used as bricks in the wall. The principal challenges us to prevent the recurrence of such atrocities.

Faced with this challenge - to prevent a situation where educated people carry out the kinds of atrocities perpetrated during World War II-we can rightly ask: do the learning outcomes - the cycle descriptors knowledge, skills and general competence-constitute a sufficient basis for higher education? The report The Framework for Qualifications of the European Higher Education Area (2005) holds that these descriptors are indeed sufficient for the totality of the qualification achieved in higher education. It argues for this view by saying that these descriptors "seek to identify the nature of the whole qualification" (ibid., p. 65). Hence it seems that these descriptors are looked upon as necessary and sufficient for capturing the quintessence of "the educated person".

I argue, however, that the cycle descriptors of knowledge, skills and general competence do not provide a sufficient basis for making individuals responsible for what they know. This is because they encourage a mode of thinking that contributes to what Kierkegaard calls "becoming objective". This attitude is rightly prized in science and scholarship inasmuch as it is concerned with reality as independent of any particular individual, but the act of being responsible resides in the realm of ethics and religion and, as such, concerns each individual as an existing being. Responsibility calls for a kind of knowledge and thinking that initiates decision making. According to Kierkegaard, knowledge in itself does not urge us to make decisions: "From the objective point of view, there is no infinite 
decision, and thus it is objectively correct that the distinction between good and evil is cancelled" (Kierkegaard 1992, p. 203). To take responsibility in relation to what one knows is about entering the realm of how rather than what: "Ethically-religiously, the emphasis is again on: how" (ibid., p. 202). But this action is not understood as the mere manner or mode in which one does a thing. Rather, it is the "relation of the existing person, in his very existence, to what is said. Objectively, the question is only about categories of thought; subjectively, about inwardness" (ibid., p. 203). To be responsible has to do with altering a relationship: "Objectively, one continually speaks only about the case in point; subjectively, one speaks about the subject and subjectivity [...] the issue is not something about the case in point but is the subjectivity itself" (ibid., p. 129).

Knowledge, skill and general competence, as outlined in official Norwegian documents, foster what Kierkegaard would recognize as reflection and objective thinking emphasizing objective knowledge. Yet, "Kierkegaard voices no objection to objective thinking as such" (Hannay 2003, p. 4), so long as it does not claim to answer questions which its terms of reference render it unfit to treat. Using an "objective" approach to help people take responsibility for the humanity in themselves would not meet the challenge, since questions about humanity require the kind of reflection involving a truth proper to religious and moral experience.

Reflecting objectively on what humanity is will not enable one to become more human, Kierkegaard argues, since to develop humanity is an existential category. Kierkegaard thus rejects an understanding that knowledge about for example ethics can enable the individual to become ethical. For him ethics has to do with becoming subjective: "That objective thinking has its reality [Realitet] is not denied, but in relation to all thinking in which precisely subjectivity must be accentuated it is a misunderstanding" (ibid., p. 93). By abstracting from the temporality of existing, pure thought removes itself from the domain of ethical and religious responsibility (Westphal 1996, p. 136). Objectively, therefore, one must bracket out what it implies to "become a human being". ${ }^{2}$ Kierkegaard claims that in "all knowing in which it holds true that the object of cognition is the inwardness of the subjective individual himself, it holds true that the knower must be in that state" and it would be a mistake to approach the subject's sincerity in an objective, reflective way (Kierkegaard 1992, p. 53). The aspect of existence is always present to the subjective thinker: "In all his thinking, then, he has to include the thought that he himself is an existing person" (ibid., p. 351). If the educational process is to foster humanity and responsibility, then a presupposition about the limits of objective thinking must be recognized. One must initiate and nurture a kind of thinking requiring a process within the individual, such that knowledge becomes relevant to the individual's own existence.

\section{Shifting Conceptions of Knowledge in Official Documents on Higher Education}

I now present some passages from official Norwegian documents mainly regarding higher education, paying special attention to how views of knowledge have changed over the last few decades. I argue that these views in official documents on higher education must be broadened if higher education is to become "education-initiating Bildung", understood as enabling people to take responsibility for their own humanity and that of others. Following

\footnotetext{
${ }^{2}$ Kierkegaard develops a distinction between being and becoming; already but not yet. He thinks we are not really what we are-human-before we are in a relation to God. If we live our lives without a relation to God, we are not what we really are. (Cf. Sygdommen til Døden [Sickness unto Death] pp. 73-74).
} 
Kierkegaard, an understanding of knowledge solely emphasizing objectivity would be unfit for such a purpose.

I use this approach because in the aftermath of the Bologna Process and the implementation of European Qualifications Framework, the triad of knowledge, skill and general competence formally either facilitates or prevents an understanding of Bildung within higher education. Without claiming that the following analysis and investigation are exhaustive, I use official Norwegian documents largely as examples, in order to revive the importance of Kierkegaard's concept of subjective thinking.

Not until the late 1980s is it possible to find an awareness of a concept of knowledge in public documents on higher education. In 1988-1989 an extended concept of knowledge is presented as a basis for the government's "knowledge policy". This is in White Paper No. 43 (1988-1989), which emphasizes that a major objective for education is to enhance the standard of knowledge and competence within education and the stages of life. The extended concept of knowledge, besides concrete factual knowledge, includes insights, attitudes and values - in other words, those things that, in a unified way, enable a person to fulfil duties and be active in the labour force and in social life (White Paper No. 43, p. 6). In the Recommendation following up White Paper No. 43 (1988-1989), lifelong-learning is presented as the knowledge policy's underlying principle.

The principle of lifelong-learning as a fundamental and collective perspective for the whole educational system presupposes a concept of knowledge that is all-encompassing. In White Paper No. 40 (1990-1991), the extended concept of knowledge is elaborated:

The goal for a comprehensive view of knowledge is to embrace and form the creative human capacity: for sake of perception, empathy, experience and participation. A view of knowledge must therefore comprise both a view of mankind and a view of society [...] The knowledge policy's goals are that individuals exercise, develop and use their abilities, that society grows increasingly humane and varied, and that the economy ensures human welfare and the preservation of nature. (White Paper No. 40

p. 18 my translation)

With this general presentation of a comprehensive view of knowledge, the document elaborates the knowledge policy's goals for individuals and society. Knowledge, the document emphasizes, is a resource that does not diminish by being shared; humanity is a value that increases when people fully use themselves for the sake of others (White Paper No. 40 (1990-1991) p. 20). This recalls Aristotle's concept of human flourishing, eudaimonia, where different approaches to various kinds of knowledge work together in the self for the sake of society. The views elaborated in White Paper No. 40 (1990-1991) have laid the foundation for subsequent thinking on higher education and for Norway's development as a knowledge society. The ultimate aim for the knowledge policy, as expressed in this and earlier white papers, is the ennobling of the human being. These documents emphasize aspects that are more in accordance with the aforementioned normative definition of Bildung, and because their view of knowledge emphasizes a process within the individual, Bildung ends up being more pronounced than in later white papers.

Other white papers and official documents from the last decade that address research and higher education are not as explicit on the issue of Bildung. White Paper No. 11 (20082009), on Teachers' Education: The Teacher-the Role and Education, states that after World War II, the teacher was seen as responsible for the "danningsprosjektet" (the great Bildung project) (ibid., p. 41), which would help create a society that would be good for everyone to live in. But apart from elaborating on the role of the teacher and presenting the new, expanded educational science subject-that is, Pedagogy and Pupil-related Skills 
(PPS), which the document asserts is geared towards nurturing values and Bildung (White Paper No. 11 (2008-2009) p. 21) - it contains few references to Bildung.

In White Paper No. 30 (2008-2009), called Climate for Research, the concept of knowledge is the main focus. The paper states that Norway today is a knowledge society where research has both instrumental and cultural justification (ibid., p. 9). It sees a good educational system as one of the most important preconditions for developing the knowledge society (ibid., p. 21). New knowledge gained through practical and theoretical research should contribute to developing Norwegian culture and civilization. Research emphasizing openness, enquiry and critical thinking will help build a well-functioning democracy (ibid., p. 9).

The vocabulary in all the white papers I have mentioned thus far balance between, on one hand, competence, outcomes, skills and transferability, and on the other hand, the intellect, knowledge, critical thinking, reflection and disciplines. Thus they promote what Barnett (1994) terms an ideology of operational competence (knowledge-how) and an ideology of academic competence (knowledge-that).

This brief look at official documents gives the impression that the white papers in the 1990s were more prone to see knowledge as the basis for personal development and to emphasize the development of humanity, whereas recent white papers imply that knowledge produced through research is transformative per se, both individually and sociopolitically. The most promising view of knowledge is given in White Paper, No. 40 (1990-1991), for it understands knowledge as something the individual is challenged by and must struggle with in his or her personal development. There is an element in this document pointing to the necessity for every individual to transform knowledge into deeper understanding. However, the kind of thinking presumed to facilitate this deeper understanding is objective reflection. Later white papers seem to conceive of the knowledge society, represented by accumulated and intellectual knowledge, as transformative in itself.

Part of the reason for this is the strong emphasis on research: higher education is tasked to produce it. The emphasis on higher education as a producer of knowledge has increased during the Bologna Process's implementation, and it has also become more common to speak of knowledge almost as a commodity in the market (Blichfeldt 2010, p. 260). The principle of research-based teaching, while enabling students to solve important challenges in society, should also enable them to become more reflective, creative and critical thinkers (White Paper No. 30 (2008-2009), p. 10). This document states that the interdependence of research and teaching exemplifies how instrumental and cultural justification interact (ibid., p. 10). The principle of research-based teaching should take care of many of the values related to general competence - that is, academic Bildung — as pointed out by the afore-mentioned UHR committee's report (UHR 2011).

Academic Bildung emphasizes reflection, creativity and critical thinking developed through research, academic development, artistic development and empirical knowledge. This type of Bildung encompasses more than one concept of knowledge. Thus the question: are these concepts of knowledge exhaustive and sufficient for enabling people to take responsibility for their humanity? The question harkens back to the school principal who, after surviving World War II, posed a challenge to all future teachers, regardless of the level at which they were teaching. In my view, the brief look at old and new official documents shows an emphasis that is moving in the wrong direction. There seems to be a shift from the emphasis on the bearer of knowledge to knowledge in itself. Knowledge in later documents is understood more as a commodity, whereas in earlier documents, integrated knowledge is emphasized, at least to some extent. The view of knowledge as a 
commodity lacks the potential to help people take responsibility for their own humanity, because fostering humanity requires a subjective emphasis.

According to Sven Erik Nordenbo (2003), people acquire Bildung only if they actively assist in its formation "In other words, in the educational context, the concept of Bildung contains a reference to an active core in the person who is gebildet" (ibid., p. 25). I now turn to the necessity of having this active element as a precondition for any concept of Bildung; hence I further investigate Kierkegaard's understanding of subjective thinking.

\section{Kierkegaard's Subjective Thinking: A Precondition for Enabling Responsibility?}

The different kinds of knowledge presented in the official documents I have discussed are essential and valuable within education, but Kierkegaard argues that another kind of insight is also necessary. A precondition for becoming ethical and hence responsible is to engage in subjective thinking. If, for example, the question is "what does it mean to be a human being?", where emphasis is on what kind of human one can be, not a human being as such, then the insight acquired through subjective thinking is a precondition for formulating the answer. The task of the subjective thinker is to understand himself or herself as an existential being.

The theme subjective thinking is especially elaborated in relation to the question of the truth of Christianity in Philosophical Fragments and The Concluding Unscientific Postscript. Kierkegaard's research question is not about the truth of Christianity or a systematic eagerness to arrange such truth, but about the individual's relation to Christianity. His inquiry focuses on the person who is infinitely interested in and driven by a deep concern for the possibility of the truth of Christianity (Kierkegaard 1992, p. 17). He discerns the objective problem to be the truth of Christianity, whereas the subjective problem is the individual's relationship to Christianity (ibid., p. 21). In the context of these problems, Kierkegaard distinguishes between two ways of thinking, one objective and the other subjective, and he discerns their hallmarks and distinctive tasks.

The concept of subjective thinking pertains to the relationship between truth and the individual: "the exister". This relationship, which contemporary philosophy pays insufficient attention to, is explored in his analysis (Evans 1983, p. 119). ${ }^{3}$

While the task of the objective thinker is to understand concrete phenomena abstractly, the subjective thinker "has the opposite task of understanding the abstract concretely" (Kierkegaard 1992, p. 352). While the objective thinker reflects on how it is to be a human being by thinking abstractly, from the concrete human being to humankind in general, "the subjective thinker understands the abstract concept to be the concrete human being, to be this individual existing human being" (ibid., p. 352). To understand oneself existentially is the Greek principle (ibid.), which, according to Kierkegaard, has to do with all questions that concern existential problems. If one "speculates" (Kierkegaard's term for thinking only in abstract categories) oneself into existential problems, one incorrectly mixes categories (ibid., p. 31). He argues that if a man, throughout his life, dedicates his thinking to logic, he will not be placing himself in the category of logic, but will continue to exist in temporal, physical categories (ibid., p. 93). Similarly, by only reflecting abstractly on existence and what it means to be human, one does not partake in the process of what Kierkegaard calls "becoming human".

\footnotetext{
${ }^{3}$ Enquiry into this theme-the connection between the individual exister and truth - can be found, for instance, in Philosophical Fragments, The Concluding Unscientific Postscript, and Two Ages.
} 
How can this distinction between subjective and objective thinking be relevant to the discussion of Bildung and the triad of knowledge, skill and general competence? In my brief elaboration of the official documents, there was little in the material to support an understanding of the existential emphasis on acquiring knowledge. One might say this is not the task of higher education, and it seems that after the Bologna process, such aims for higher education are toned down to the point of being almost non-existent.

Higher educational aims, I believe, should also facilitate a thinking that enables individuals to take responsibility for the humanity in their own person, just as the aforementioned school principal stressed. Therefore, we need another understanding of how to gain insight into humanity other than through objective thinking. Objective knowledge and reflection as such do not move one to make decisions; the subject must allow the specific knowledge to make an impact on his or her own life: "reflection cannot be stopped objectively, and when it is stopped subjectively, it does not stop of its own accord, but it is the subject who stops it" (Kierkegaard 1992, p. 116). Facts in themselves do not trigger action but subjectivity does: "As soon as subjectivity is taken away, and passion from subjectivity, and infinite interest from passion, there is no decision whatever [...] All decision, all essential decision, is rooted in subjectivity" (ibid., p. 33).

"What is humanity?" therefore cannot be answered by treating humanity as a case, says Kierkegaard; it can only be answered by engaging in existence. For this reason, questions about humanity and about "becoming human" cannot be lectured on in an objective fashion, since these are questions of a subjective kind. To illustrate the difference between objective and subjective thinking, I quote Alasdair MacIntyre's summary of knowledge about human beings as seen from different disciplines:

From the standpoint of physics human beings are composed of fundamental particles interacting in accordance with the probabilistic generalizations of quantum mechanics. From that of chemistry we are the sites of chemical interactions, assemblages of elements and compounds. From that of biology we are multicellular organisms belonging to species each of which has its own evolutionary past. From that of historians we are intelligible only as emerging from long histories of social and economic transformations. From that of economists we are rational profitmaximizing makers of decisions. From that of psychology and sociology we shape and are shaped by our perceptions, our emotions, and our social roles and institutions. And from that of students of literature and the arts it is in the exercise of our various imaginative powers that we exhibit much that is distinctive about human beings. (MacIntyre 2009, p. 175)

If this quote summarizes the objective knowledge about what a human being is, particularly as taught within higher education, then this knowledge in itself does not help me take responsibility for my humanness because it gives me no unifying understanding of what it is to be human, either generally or as a unique singular individual. If all the multifarious forms of knowledge point in different directions, how am I to learn to act as a human being, in relation to what kind of human being I can be? How can I take responsibility for my life?

In relation to such questions Kierkegaard distinguishes between two types of truth: first, to "be in truth" (psychological truth), or living according to one's convictions, concerns the relationship between knowledge and the knower. This is what Kierkegaard calls subjective truth: "Subjective truth, according to Kierkegaard, is a way of existing" (Piety 2010, p. 100). The second is truth as such; it concerns the relationship between the subject and the object (propositional knowledge, i.e., knowledge-that) and the question of truth. 
Kierkegaard asks: what is the relation between a proposition and an existing human being? Furthermore, how can a psychological entity, such as a belief, be true? When investigating knowledge-that propositions, there are different approaches to justification, for example correspondence, coherence and pragmatic theories of truth. Hence the diverse statements in the MacIntyre quote about what a human being is can be analysed according to various theories of truth. But this would entail analysing the statements as propositions and not in relation to one's life as an existential being. So, how can the relationship between an individual subject and truth be investigated? This is what Kierkegaard regards as the most important truth - to be true as a subject - and this is only possible if one truly becomes subjective (Kierkegaard 1992, p. 131). Subjective truth, in Kierkegaard's thinking, is like the self as pointed out by Piety (2010); "subjective truth, like the self, does not actually exist [...] but is simply that which ought to exist" (ibid., p. 102).

Objectively, it is possible to investigate the different propositions about what a human being is according to various theories of truths. We would then focus on what a human being is as such, and in Kierkegaard words, become a book. If " $[t]$ he thinker who in all his thinking can forget to think conjointly that he is existing does not explain existence; he makes an attempt to cease to be a human being, to become a book or an objective something" (Kierkegaard 1992, p. 93). We would then be moving away from ourselves as subjects - as unique human beings. If we are going to treat the knowledge about human beings, as expressed in the MacIntyre quote, in terms of subjective thinking, we must, as existential beings, be deeply concerned about the possibility of the truth of these propositions, turning them into ethical demands in relation to what it existentially means to be an existing individual.

If analysing a belief such as "human beings are rational profit-maximizing makers of decisions" as an objective and exhaustive truth about what a human being is, we could analyse it as either a psychological event or as an action, but the belief could also be analysed in terms of its content. This content can thus be expressed in a proposition. ${ }^{4}$ Accordingly, the problem of beliefs being true or false is converted into the problem of propositions being true or false and justified through various theories of truth. When the matter of beliefs is only approached as a mental concern, we as existers become increasingly objective and move away from ourselves as subjects. If we were to investigate whether the belief "human beings are rational profit-maximizing makers of decisions" is true or false by converting it into a proposition, we would never find genuine truth, which, according to Kierkegaard, is essential truth. He is what Evans calls a modest epistemologist, where the goal of epistemology is simply to become clearer about what knowledge is and how it is acquired (Evans 2006, p. 186). According to Kierkegaard, the kind of relationship between an exister and the truth that is possible is something essential for the exister to obtain. It is "essential truth or the truth that is related essentially to existence" (Kierkegaard 1992, p. 199 note). It is essential truth because it is related to the essence of an individual's existence as such and not to being an example of a human in general-this is also referred to as "subjective truth" (Piety 2010, p. 100). Essential, subjective truth concerns the relationship between the possibilities of a case being true and the exister's own life. It is in this context that Kierkegaard puts forth the definition of truth as subjectivity. This definition is not intended to apply to logic, history and other areas where the particular kind of truth does not essentially bear on existence. Rather, it "is simply the truth about how to live" (Evans 1983, p. 123).

\footnotetext{
${ }^{4}$ In relation to the previous argument I am indebted to Stephen Evans analysis of subjective knowledge.
} 
Consequently, if a human being is a "rational profit-maximizing makers of decisions", how do I then live a true life as a human being, and what, from this perspective, is my humanness and responsibility as an exister? If I only think about this abstractly, I will never come to know and experience the consequences of such a belief. However, if I engage in life and live out the consequences of this understanding of what it is to be a human being in relation to my own existence, I will experience the truth of the content of the proposition, subjectively. Human beings as thinkers are first and foremost persons in existence. Thinking about what a human being is must therefore include something other than making various knowledge-that propositions about human beings.

Subjective knowledge, however, is not to be equated with subjectivism. Kierkegaard develops an approach to subjective knowledge that makes it possible to have justified beliefs about psychological truths. The main concern for truth as subjectivity is the question "Can a life be true"? His notion of "essential truth" as subjective truth does not point to whether a thought is true, but to putting the thought into practice, and it relates especially to ethical and ethical-religious knowledge.

As such, thinking makes ethical demands. Kierkegaard holds that truths concerning subjectivity require a different justification than propositional knowledge. There are no truth-tables in logical theory for whether a life can be true. But when a subject, an exister, transforms his or her thinking into reality, living it out in existence, then the exister is "in the truth", and his or her existence may be described as true. This process of living out one's own thinking as an ethical demand takes into account the realization that the truth about existence is a process. Truth is more than an ideal; it becomes actualized in time, as lived experience. Truth for Kierkegaard is not just something to be known, but something to be appropriated in inwardness; it must be acted on (Perkins 2002). If we are to be responsible, subjective knowledge is necessary, says Kierkegaard, and this knowledge involves contact with or participation in the reality in question. Subjective knowledge proper is not the product of an observation of reality. Subjective knowledge, as pointed out by Piety, is restricted to certain kinds of objects: "knowledge of God, self-knowledge, and ethical-religious knowledge [...] [subjective knowledge] is the product of the participation of the knower in that reality" (Piety 2010, pp. 96-7).

All essential knowing pertains to existence, or only the knowledge whose relation to existence is essential knowing. Essentially viewed, the knowing that does not inwardly in the reflection of inwardness pertain to existence is accidental knowing, and its degree and scope, essentially viewed, are a matter of indifference [...] it means that the knowledge is related to the knower, who is essentially an existing person and that all essential knowing is therefore related to existence and to existing. Therefore, only ethical and ethical-religious knowledge is essential knowing. But all ethical and all ethical-religious knowing is essentially a relating to the existing of the knower. (Kierkegaard 1992, pp. 197-8)

Kierkegaard uses different concepts to analyse this process of subjective truth and essential knowledge. ${ }^{5}$ The justification for subjective truths and subjective thinking is their upbuilding character. ${ }^{6}$ Returning again to MacIntyre's review of statements about what a human being is; according to Kierkegaard, the subjective truth of these statements resides

\footnotetext{
5 Through indirect communication, Kierkegaard presents his "doctrine of the stages" (the aesthetic, ethical and religious life) and evaluates the "upbuilding" capacity of different ways of living.

${ }^{6}$ For an elaboration of upbuilding as a pedagogical concept, see Wivestad (2012a, b).
} 
in the upbuilding capacity they have in one's own existence, when they are lived out as true statements about what it essentially means to be human.

The following story, developed by Robert L. Perkins (2002), illustrates the upbuilding character of Kierkegaard's understanding of subjective thinking and his justification of subjective truth:

Suppose two mothers, both of whose sons are accused of a crime. Both want to believe their sons innocent, but their attitude is entirely different. One mother wants her son to be cleared, to be declared innocent and she does all she can to ascertain the fact in order that her son can be found innocent. However she is willing to let the facts stand; she does not tinker with, suppress, or deny what does not support what she desires. Now, the truth may turn out either way, but this mother's relation to the truth is that the subjectivity is the truth. She will act on the basis of innocence till the facts declare one way or the other. Even if the son were guilty, it would deprive neither him nor her of love. This mother's attitude to the truth is upbuilding. The other mother wishes also that her son will be found innocent. She, however, will suppress or deny facts and look the other way in order to maintain her son's innocence. She is willing to deceive herself, to lie to herself, and therefore her attitude is not upbuilding...The first mother will be built up by her respect for the truth, the second mother will be diminished if not finally destroyed by her disrespect for truth... according to Kierkegaard's view of upbuilding and subjective truth, the first mother will be edified even if her son is guilty and the second mother diminished even if her son is proven innocent. (Perkins 2002, p. 233)

Upbuilding as justification for the truth of subjectivity is relevant to someone in the "process of becoming", as a result of subjective thinking. The two mothers will live different lives as a result of how they choose to live in the truth. Similarly, if we live according to what we believe we as human beings are, we will experience the upbuilding character ${ }^{7}$ these understandings have when transformed into lived experience.

\section{Concluding Remarks}

When Dannelsesutvalget's committee discussed the Bologna descriptors, it saw no problems with them in themselves, but recommended that the contents of higher education should be revised in the direction of a liberal arts tradition-a tradition that often emphasizes different modes of knowledge. The UHR committee was more reluctant to adopt such a recommendation, since it was sceptical as to whether knowledge about Bildung results in Bildung. The UHR committee put forward an understanding of Bildung as internalized knowledge and competence "that which is left when what we have learned is forgotten" (UHR 2011, p. 34). I agree with the UHR committee in its emphasis on internalized knowledge as an important aspect in conceptualizations of Bildung, but I have argued, on the background of how knowledge is outlined in official Norwegian documents, that the concept of knowledge is moving in a wrong direction: it is becoming a commodity to be traded in a market with its own transformative power. If the Bologna descriptors embedded in higher education are meant to be able to initiate Bildung, I hold that we must work for a different understanding of knowledge, one which is not solely objective and

\footnotetext{
${ }^{7}$ Upbuilding serves as a justification in relation to objects of knowledge that pertain to subjective knowledge (knowledge of God, self-knowledge, and ethical-religious knowledge).
} 
objectified. My intention has thus been mostly to point out the limits of the triad knowledge, skill and general competences summed up as learning outcomes in relation to preconditions for Bildung on the background of official documents references to the "knowledge society". If higher education shall enable responsibility, it must initiate a thinking that involves entering the realm of ethics and not just learning about it as a subject. To this end, subjective thinking is important because it elaborates the existential challenge "to be in the truth" understood as correspondence between what one holds as true and ones way of living. This implies that educators within higher education should also see the process of how knowledge becomes internalised as their task initiating an approach to knowledge as also entailing the question of subjective truth. Kierkegaard's concept of subjective thinking can clear the haze surrounding the question of how knowledge can become both integrated and influential in a person's life. Subjective thinking, I believe, can illuminate and contribute to what Biesta and Säfström (2011) call the ethics of subjectivity, which point to the preconditions for education.

Acknowledgments I thank Gert Biesta, Herner Saeverot and Stein M. Wivestad for giving me constructive comments on earlier drafts of this paper. A special thank to Gert for being positive to the idea of a special publication on existential issues in education.

Open Access This article is distributed under the terms of the Creative Commons Attribution License which permits any use, distribution, and reproduction in any medium, provided the original author(s) and the source are credited.

\section{References}

Act of Universities and University Colleges 2005, Section 1-3 [Lov om universiteter og høyskoler (universitets- og høyskoleloven]. (2005). http://www.ub.uio.no/ujur/ulovdata/lov-20050401-015-eng.pdf. Accessed August 13, 2012.

Barnett, R. (1994). The limits of competence: Knowledge, higher education and society. Buckingham: Society for Research into Higher Education \& Open University Press.

Biesta, G. J. J. (2006). Beyond learning democratic education for a human future. Boulder, CO: Paradigm.

Biesta, G. J. J., \& Säfström, C. A. (2011). Ett manifest för pedagogik [A manifesto for education]. Utbildning \& Demokrati, 20(3), 83-95.

Blichfeldt, J. F. (2010). On knowledge bases and maps of knowledge: Some quiddities on getting to know in contemporary higher education. Nordic Studies in Education, 30(4), 252-265.

Bologna Declaration of 19 June 1999. http://eu.daad.de/imperia/md/content/eu/bologna/bolognadeclaration. pdf. Accessed August, 2012.

Bologna Follow-up Group. (2009). Bologna beyond 2010: Report on the development of the European higher education area. Leuven: Louvain-la-Neuve Ministerial Conference. http://www.ond.vlaanderen.be/hoge ronderwijs/bologna/conference/documents/Beyond_2010_report_FINAL.pdf. Accessed August, 2012.

Bologna Working Group on Qualifications Frameworks. (2005). A framework for qualifications of the European higher education area. Copenhagen: Ministry of Science, Technology and Innovation. http://www.joint quality.n1/content/ierland/draft_report_qualification_framework_EHEA2.pdf Accessed August, 2012.

Bostad, I. et al. (2009). Kunnskap og dannelse foran et nytt århundre [Knowledge and Bildung at the start of a new century]. Oslo: Dannelsesutvalget, University of Oslo.

Budapest-Vienna Declaration on the European Higher Education Area of March. 2010. http://global highered.files.wordpress.com/2010/03/budapest-vienna_declaration.pdf. Accessed August, 2012.

Committee on Yale College Education Working Groups. (2003). Report on Yale College Education. New Haven, CT: Yale College. http://www.yale.edu/yce/report/cycereport.pdf Accessed March, 2012.

Evans, C. S. (1983). Kierkegaard's 'Fragments' and 'Postscript': The religious philosophy of Johannes Climacus. Atlantic Highlands, NJ: Humanities.

Evans, C. S. (2006). Kierkegaard on faith and the self: Collected essays. Waco: Baylor University Press.

Fejes, A. (2008a). Standardising Europe: The Bologna Process and new modes of governing learning and teaching, 1(2), 25-49.

Fejes, A. (2008b). European citizens under construction: The Bologna Process analysed from a governmentality perspective. Educational Philosophy and Theory, 40(4), 515-530. 
Hagtvet, B., \& Ognjenovic, G. (2011). Dannelse: Tenkning, modning, refleksjon: Nordiske perspektiver på allmenndannelsens $n \phi d v e n d i g h e t ~ i$ høyere utdanning og forskning [Bildung: Thinking, maturation, reflection: Nordic perspectives on the necessity of liberal arts in higher education and research]. Oslo: Dreyer.

Hannay, A. (2003). Kierkegaard and philosophy: Selected essays. London: Routledge.

Horlacher, R. (2004). Bildung-A construction of a history of philosophy of education. Studies in Philosophy and Education, 23(5-6), 409-426.

Kierkegaard, S. (1963). En literair anmeldelse [Two Ages] ved J. L. Heiberg (3rd ed., Vol. 14).

Kierkegaard, S. (1963). Sygdommen til Doden [Sickness unto Death] ved A. B. Drachmann. (3rd ed., Vol. 15).

Kierkegaard, S. (1985). Philosophical fragments: Johannes climacus (H. V. Hong \& E. H. Hong, Trans.). Princeton, NJ: Princeton University Press.

Kierkegaard, S. (1992). Concluding unscientific postscript to philosophical fragments (H.V. Hong \& E. H. Hong, Trans.). Princeton, NJ: Princeton University Press.

Lieberkind, J., \& Bergstedt, B. (2005). Dannelse mellem subjektet og det almene: En antologi. [Bildung between the subject and the universal: An anthology]. Copenhagen: Danmarks pædagogiske universitets forlag.

Love, K. (2008). Higher education, pedagogy and the 'customerisation' of teaching and learning. Journal of Philosophy of Education, 42(1), 15-34.

Løvlie, L., Mortensen, K. P., \& Nordenbo, S. E. (Eds.). (2003). Educating humanity: Bildung in postmodernity. Malden, MA: Blackwell Publ.

Løvlie, L., \& Standish, P. (2003). Introduction: Bildung and the idea of a liberal education. In L. Løvlie, K. P. Mortensen, \& S. E. Nordenbo (Eds.), Educating humanity: Bildung in postmodernity (pp. 1-24). Malden, MA: Blackwell Publication.

MacIntyre, A. (2009). God, philosophy, universities: A selective history of the Catholic philosophical tradition. Lanham: Rowman \& Littlefield.

Masschelein, J., \& Ricken, N. (2003). Do we (still) need the concept of bildung? Educational Philosophy and Theory, 35(2), 139-154.

Nordenbo, S. E. (2003). Bildung and the thinking of Bildung. In L. Løvlie, K. P. Mortensen, \& S. E. Nordenbo (Eds.), Educating humanity: Bildung in postmodernity (pp. 25-36). Malden, MA: Blackwell Publication.

OECD. (2001). The well-being of nations-The role of human and social capital. Paris: OECD. http:// www.oecd.org/site/worldforum/33703702.pdf. Accessed September, 2012.

Perkins, R. L. (2002). Kierkegaard, a kind of epistemologist. In D. W. Conway \& K. E. Gover (Eds.), S $\phi r e n$ Kierkegaard: Critical assessments of leading philosophers (Vol. 2, pp. 224-236). London: Routledge.

Piety, M. G. (2010). Ways of knowing: Kierkegaard's pluralist epistemology. Waco: Baylor University Press.

Rise, S. (2010). Danningsperspektiver: Teologiske og filosofiske syn på danning $i$ antikken og $i$ moderne tid [Perspectives on Bildung: Theological and philosophical views on Bildung in antiquity and in modern times]. Trondheim: Tapir akademisk forl.

Schneider, K. (2012). The subject-object transformations and 'Bildung'. Educational Philosophy and Theory, 44(3), 302-311.

Strom, M. S., \& Parsons, W. S. (1994). Facing history and ourselves: Holocaust and human behavior. Watertown, MA: Intentional Educations.

Sünker, H. (2006). Politics, Bildung and social justice: Perspectives for a democratic society. Rotterdam: Sense Publishers.

Thompson, C. (2005). The non-transparency of the self and the ethical value of Bildung. Journal of Philosophy of Education, 39(3), 519-533.

UHR. (2011). Dannelsesaspekter $i$ utdanningen. Rapport fra arbeidsgruppe nedsatt av UHRs utdanningsutvalg, September 2011. [Report from The Norwegian Association of Higher Education Institutions]. http://www.uhr.no/documents/DannelseRapportEndelig.pdf. Accessed December, 2011.

Wahlström, N. (2010). Do we need to talk to each other? How the concept of experience can contribute to an understanding of Bildung and democracy. Educational Philosophy and Theory, 42(3), 293-309.

Westphal, M. (1996). Becoming a self: A reading of Kierkegaard's concluding unscientific postscript. West Lafayette, IN: Purdue University Press.

White Paper No. 43. (1988-1989). Mer kunnskap til flere [More knowledge to even more]. Oslo: Kirke- og undervisningsdepartementet.

White Paper No. 40. (1990-1991). Fra visjon til virke: Om høgre utdanning [From vision to action: On higher education] Oslo: Kirke, utdannings-og forskningsdepartementet.

White Paper No. 30. (2008-2009). Klima for forskning. [Climate for research] Oslo: Kunnska psdepartementet. 
White Paper No. 11. (2008-2009). Lareren: Rollen og utdanningen. [The teacher-The role and education] Oslo: Kunnskapsdepartementet.

Wivestad, S. M. (2012a). On becoming better human beings: Six stories to live by. Studies in Philosophy and Education,. doi:10.1007/s11217-012-9321-8.

Wivestad, S. M. (2012b). 'Upbuilding examples' for adult close to children. Studies in Philosophy and Education,. doi:10.1007/s11217-012-9327-2. 